https://doi.org/10.52058/2786-4952 -2021-4(4)-61-72

Бірюкова Тетяна Вікторівна кандидат технічних наук, доцент, доцент кафедри біологічної фізики та медичної інформатики, Буковинський державний медичнмй університет, вул. О.Кобилянської, 42, м. Чернівці, 58000, тел.: (0372) 52-45-44, e-mail: tanokbir@ukr.net, https://orcid.org/0000-0003-4112-7246

Сукач Тетяна Миколаївна кандидат педагогічних наук, доцент, викладач математики, Відокремлений структурний підрозділ «Київського фахового коледжу комп'ютерних технологій та економіки Національного авіаційного університету», вул. Бориспільська, 5, м. Київ, 02099, тел.: (044) 566-01-88, e-mail: sukach1@ukr.net, https://orcid.org/0000-0003-1053-9002

Чуйков Артем Сергійович кандидат фізико-математичних наук, викладач математики, Відокремлений структурний підрозділ «Київського фахового коледжу комп'ютерних технологій та економіки Національного авіаційного університету», вул. Бориспільська, 5, м. Київ, 02099, тел.: (044) 566-01-88, e-mail: chyikov.artem@gmail.com, https://orcid.org/0000-0002-0945-0396

\title{
ФОРМУВАННЯ ПРОФЕСІЙНИХ КОМПЕТЕНТНОСТЕЙ ЗДОБУВАЧІВ ВИЩОЇ ТА ПЕРЕДВИЩОЇ ОСВІТИ ЗАСОБАМИ ДИФЕРЕНЦАЛЬНОГО ЧИСЛЕННЯ
}

Анотація. В статті розглянуто методичні та дидактичні аспекти формування професійних, математичних компетентностей здобувачів вищої та передвищої освіти при вивченні теми «Диференціальне числення функції однієї змінної» студентами технічних та економічних спеціальностей ВСП «КФКТЕ НАУ».

Сучасний етап функціонування вищої та передвищої професійної освіти вимагає нових підходів до підготовки конкурентоспроможних фахівців, які здобувають під час навчання не лише можливості оперувати отриманими знаннями, а й здатні пристосовуватися до потреб сучасного ринку праці.

Основною метою викладання математики, вищої математики в коледжі вважаємо формування у студентів навичок застосування математичного апарату в задачах прикладної, професійної спрямованості.

Сучасні вимоги до здобувачів вищої та передвищої освіти значно підвищують роль математичної підготовки, яка полягає в успішному застосуванні математичного апарату до розв'язання практичних задач, задач професійної спрямованості. Актуальним є питання формування у студентів, як професійних, так і математичної компетентностей засобами математичного апарату, що в свою чергу підвищує значущість вивчення предмету. 
Журнал«Герспективита інновації науки

(Серія«Гедагогіка», Серія«Гцихологія», Серія«Медицинв»

№4(4) 2021

Розв'язання прикладних задач, задач професійної спрямованості значно підвищує пізнавальну активність студентів, здатність до самостійного пошуку додаткових теоретичних знань, підвищує вмотивованість застосування набутих знань 3 математики в майбутній професійній діяльності. Застосування прикладних задач, економічних задач $є$ ефективним засобом формування творчої особистості, сприяє формуванню як математичних, так i професійних компетентностей.

Забезпечити професійну спрямованість навчання, як це визначено нормативними документами, можливо за рахунок включення прикладних задач, зміст яких відповідає профілю навчання.

Для викладачів коледжу, які працюють із студентами різних спеціальностей найбільш суттєвим $є$ набуття студентами математичних компетентностей, які допоможуть застосовувати математичний апарат в майбутній професійній діяльності.

Ключові слова: коледж, компетентність, математична компетентність, прикладні задачі, практичні задачі, диференціальне числення.

Biriukova Tetiana Viktorivna Ph.D. in Technical Sciences, Associate Professor of Department of Biological Physics and Medical Informatics, Bukovinian State Medical University, O. Kobylyanska St., 42, Chernivtsi, 58000, tel.: (0372) 52-45-44, e-mail: tanokbir@ukr.net, https://orcid.org/0000-0003-4112-7246

Sukach Tatiana Mykolayivna Ph.D., Associate Professor, Department of Programming and Mathematics, Kiev College of Computer Technology and Economics of National Aviation University, Boryspilska St., 5, Kyiv, 02099, tel .: (044) 566-01-88, e-mail: sukach1@ukr.net, https://orcid.org/0000-0003-1053-9002

Chuikov Artem Serhiiovych Ph.D. in Physical and Mathematical Sciences, Department of Programming and Mathematics, Kiev College of Computer Technology and Economics of National Aviation University, Boryspilska St., 5, Kyiv, 02099, tel.: (044) 566-01-88, e-mail: chyikov.artem@gmail.com, https://orcid.org/0000-0002-0945-0396

\section{FORMATION OF PROFESSIONAL COMPETENCIES OF APPLICANTS OF HIGHER AND PREVIOUS EDUCATION BY MEANS OF DIFFERENTIAL NUMBERING}

\footnotetext{
Abstract. The article considers methodical and didactic aspects of formation of professional, mathematical competencies of higher and higher education students in studying the topic "Differential calculus of the function of one variable" by students of technical and economic specialties of VSP "KFKTE NAU".

The current stage of functioning of higher and higher professional education requires new approaches to the training of competitive professionals who gain during
} 
training not only the opportunity to operate with the acquired knowledge, but also able to adapt to the needs of the modern labor market.

The main purpose of teaching mathematics, higher mathematics in college is the formation of students' skills in applying the mathematical apparatus in problems of applied, professional orientation.

Modern requirements for students of higher and higher education significantly increase the role of mathematical training, which consists in the successful application of the mathematical apparatus to solve practical problems, problems of professional orientation. The issue of formation of students, both professional and mathematical competencies by means of mathematical apparatus is relevant, which in turn increases the importance of studying the subject.

Solving applied problems, problems of professional orientation significantly increases the cognitive activity of students, the ability to independently search for additional theoretical knowledge, increases the motivation to apply the acquired knowledge of mathematics in future professional activities. The use of applied problems, economic problems is an effective means of forming a creative personality, promotes the formation of both mathematical and professional competencies.

To ensure the professional orientation of training, as defined by regulations, it is possible by including applied tasks, the content of which corresponds to the profile of training.

For college teachers who work with students of different specialties, the most important thing is the acquisition by students of mathematical competencies that will help to apply the mathematical apparatus in future professional activities.

Keywords: college, competence, mathematical competence, applied problems, practical problems, differential calculus.

Постановка проблеми. Сучасний етап функціонування вищої та передвищої професійної освіти вимагає нових підходів до підготовки конкурентоспроможних фахівців, які здобувають під час навчання не лише можливості оперувати отриманими знаннями, а й здатні пристосовуватися до потреб сучасного ринку праці.

Базовою ідеєю реформування освіти, як у країнах Європейського Союзу, так і в Україні, визнано компетентнісний підхід. Компетентнісний підхід в освіті $\epsilon$ одним із основних концептуальних положень оновлення змісту освіти та підвищення іï якості.

Професійна компетентність фахівця, як зазначає М.Ю. Кадемія, «передбачає розв'язання різного роду проблем, завдань на основі наявного досвіду, знань і цінностей, а професійні компетенції передбачають здатність людини успішно діяти в процесі своєї професійної діяльності, що робить можливим бути професійно успішним будь-якого випускника навчального закладу» [4, с. 39].

У процесі підготовки майбутнього фахівця важливо правильно сформувати його професійну компетентність, яка включає: здатність фахівця кваліфіковано виконувати свою роботу, вміння швидко опановувати сучасні досягнення в 
Журнал«Герспективитаінновації науки»

(Серія«Гедагогіка», Серія«Гцихологія», Серія«Медицинв»

№4(4) 2021

обраній галузі, збагачення своїх знань, досвіду практичної діяльності, вдосконалення умінь і навичок самостійно, оперативно приймати рішення в нестандартних ситуаціях » [3, с. 12].

Сучасні вимоги до здобувачів вищої та передвищої освіти значно підвищують роль математичної підготовки, яка полягає в успішному застосуванні математичного апарату до розв'язання практичних задач, задач професійної спрямованості. Актуальним є питання формування у студентів, як професійних, так і математичної компетентностей засобами математичного апарату, що в свою чергу підвищує значущість вивчення предмету.

На прикладі вивчення «Диференціального числення функції однієї змінної» продемонструємо вивчення розділу студентами коледжу ВСП «КФКТЕ НАУ» спеціальностей 172 «Телекомунікації та радіотехніка» та 051 «Економіка».

Аналіз останніх досліджень і публікацій. Вивченням та аналізом поняття «компетентність» займаються багато вчених. Компетентність досліджували: С.П. Бондар, М.С. Головань, С.У. Гончаренко, І.В. Родигіна, Г.К. Селевко, А.В. Хуторський, М.Ю. Кадемія, Т. В. Ткаченко, Л.С. Отрощенко, О.Б. Лисак, C.Є. Шишов та ін. Значний внесок у розвиток теоретико-методологічних засад упровадження компетентнісного підходу зробили зарубіжні і українські вчені, зокрема: І. Демура, Б. Авво, А. Бермус, Ю. Татур, А. Вербицький, І. Зимня, М. Князян, Б.С. Гершунський, А. Маркова, А. Митяєва, Л. Морська, О. Овчарук, В. Краєвський, В. Петрук, Д. Погонишева, О. Савченко, О. Субетто, С. Трубачева, О. Локшина та ін.

Професійна компетентність молодшого бакалавра формується «на засадах теоретичних знань, практичних умінь, значущих особистісних якостей та життєвого досвіду, що зумовлює готовність фахівця до виконання професійних обов’язків та забезпечує високий рівень його самоорганізації». [8, с. 7]

«Компетентність визначає якості і рівень професійної готовності до діяльності, що виражається в характері праці, здатності в умовах різних труднощів знаходити раціональні рішення виниклої проблеми. Ріст компетентності сполучений із самоаналізом і самооцінкою особистості, які $\epsilon$ внутрішнім стимулом професійного самовизначення». [7 , с. 26]

Серед складових компетентностей важливе значення мають математичні компетентності, призначені для дослідження реальності за допомогою математичних моделей.

Математична компетентність виражається в спроможності особистості бачити та застосовувати математику в реальному житті, розуміти зміст і метод математичного моделювання, інтерпретації отриманих результатів.

Для викладачів математики в коледжі, виші постає задача навчити майбутніх фахівців застосуванню математичного апарату для успішного розв'язання професійних задач, що в свою чергу неможливо без розв'язання практичних, професійноориєнтованих завдань з різних тем курсу.

Для молодших бакалаврів як технічного, так i економічного напрямів 
математика є інструментом розв’язання практичних задач, задач професійної спрямованості.

Окремі питання професійної спрямованості вивчення математичного аналізу у вищій школі та коледжах розглядали в своїх дослідженнях О.В. Авраменко, O.M. Архіпова, Ф.А. Бабаєва, Г.І. Баврін, Л.І Дюженкова, М.І. Жалдак, Т.В. Колесник, В.І. Лагно, М.Я. Лященко, О.О. Максютін, М.А. Меркулова, Г.О. Михалін, С.М. Мумряєва, Ф.Л. Осипов, Н.В. Перькова, О.В. Скворцова, O.П. Томащук, T.I. Шахматова, M.I. Шкіль.

Одним із ефективних засобів реалізації прикладної спрямованості навчання математичного аналізу є прикладні задачі - задачі, що виникають за межами математики, але розв'язування яких вимагає застосування математичного апарату.

Питання добору прикладних задач, методів їх розв'язання, шляхів формування вмінь розв'язувати прикладні задачі за допомогою математичного моделювання досліджували Г.П. Бевз, С.I Великодний, Н.M. Войналович, А.Б. Дмитрієва, Г.Я. Дутка, Т.М. Задорожня, О.О. Курченко, М. Нассер, Л.І. Новицька, Л.Л. Панченко, В.О. Петров, А.В. Прус, К.В. Рабець, Л.О. Соколенко, Л.Г. Філон, В.О. Швець, Й.М. Шапіро.

Однак проблема добору прикладних задач викладачами та навчання студентів розв'язувати такі задачі в процесі навчання математичного аналізу залишається недостатньо розробленою.

Мета статті - визначення впливу розв'язання прикладних, професійно орієнтованих задач 3 диференціального числення на рівень вмотивованості навчання на рівень математичної підготовки в розв'язуванні професійних завдань, які допоможуть майбутньому фахівцю в професійному становленні; розкриття шляхів реалізації прикладної спрямованості курсу Вищої математики за допомогою системи прикладних задач у процесі навчання студентів коледжу різних спеціальностей.

Виклад основного матеріалу. Одним із основних напрямів реформування вищої та передвищої освіти в Україні, як і у всьому цивілізованому світі $\epsilon$ компетентнісно орієнтована освіта, яка формує у студентів компетентності, необхідні в житті.

Головними завданнями вивчення математики студентами коледжу $\epsilon$ здобуття знань, вмінь, навичок застосування математичного апарату в професійній діяльності, що допоможе майбутнім фахівцям стати успішними, конкурентоспроможними на ринку праці.

Роль розв'язання прикладних задач із застосуванням диференціального числення розглянули в своїх наукових працях Соколенко Л., Сухорукова Е., Шаповалова Л., Бурда М., Колягин Ю., Саранцев Г., Слєпкань 3., Столяр О., Раков С. та ін.

Проблеми формування математичних компетентностей розглянуті в дослідженнях науковців Г. Гапоненко, М. Маслової, О. Белянинової, М. Зуєвої, 
Журнал«Герспективитаінновації науки»

(Серія«Гедагогіка», Серія«ГЕихологія», Серія«Медицина»

№4(4) 2021

С. Ракова, І.Срмакова, С. Шишова, О. Біди, Н. Бурдинської, В. Ільченко, С. Ніконова та ін.

Проблеми вивчення математики, вищої математики в коледжах полягає в розробці технологій навчання, які реалізують професійну спрямованість вивчення предмету.

Під навчальними задачами 3 професійним змістом дослідниця Кашканова Г.Г. розуміє приклади і задачі, що відображають специфіку майбутньої професійної діяльності студентів [5, с. 17$]$

Реалізація професійної спрямованості математики, вважає Фомкіна О.Г., і застосування іiі засобів у сфері виробництва, економіки, фінансів, менеджменту відбувається шляхом впровадження в навчальний процес математичних задач 3 економічним змістом [10, с. 12]

Значну роль прикладних задач із застосуванням диференціального числення розглянули у своїх працях Соколенко Л., Сухорукова Е., Шаповалова Л., Бурда М., Колягін Ю., Саранцев Г., Слєпкань 3., Столяр О., Раков С. та ін.

Розглянемо на прикладах можливість застосування теорії диференціального числення для розв'язання задач професійної спрямованості студентами коледжу ККТЕ НАУ спеціальності 172 «Телекомунікації та радіотехніка», 133 «Галузеве машинобудування».

\section{Застосування похідної в фізиці.}

Відомо, що похідна $f^{\prime}\left(x_{0}\right)$ характеризує швидкість зміни функції $y=f(x)$ в точці $x_{0}$ у напрямі осі $O x$.

1) Якщо відомий закон руху $S=S(t)$, то швидкість руху у момент $t_{0} \quad \epsilon$ похідна за часом: $V\left(t_{0}\right)=S^{\prime}\left(t_{0}\right)$.

2) 3 механічної точки зору друга похідна від шляху за часом $\epsilon$ прискорення pyxy: $a(t)=S^{\prime \prime}(t)=V^{\prime}(t)$.

3 ) Для визначення струму в момент часу $t$ (миттєвого струму), якщо кількість електрики, що протікає у колі за проміжок $\Delta t$ і дорівнює $q(t)$, використовується формула $I=\frac{d q}{d t}=q^{\prime}(t)$.

4) При нагріванні стрижня його довжина є функцією температури $T$ : $l=l(T)$. Тоді для визначення коефіцієнта лінійного розширення $\alpha$ при температурі $T$ застосовується формула $\alpha=l^{\prime}(T)$.

5) Напруга конденсатора змінюється за синусоїдальним законом $U=U_{m} \cdot \sin \omega t$. Тоді обчислення величини електричного струму $i$, що протікає через конденсатор, якщо $i=\frac{d q}{d t}, q=c U, c, U_{m}$ - сталі, ведеться за формулою $i=c U_{m} \omega \sin \left(\omega t+90^{\circ}\right)$.

6) Якщо рух точкової маси $m$ описується законом згасаючих коливань $S=A e^{-k t} \cdot \sin \omega \cdot t(A, k, \omega>0)$, то: 


$$
\begin{aligned}
& \text { - швидкість руху } V \text { обчислюється за формулою } \\
& V=A e^{-k t} \cdot(\omega \cos \omega t-k \sin \omega t) \text {; } \\
& \text { прискорення: } a=-\left(\omega^{2}+k^{2}\right) S-2 k V ; 2 \\
& \text { - } \quad \text { сила } F \text {, під дією якої відбувається рух: } F=m a \text {. }
\end{aligned}
$$

7) Потужність є похідна роботи за часом: $N=A^{\prime}(t)$.

8) Сила струму $є$ похідна заряду за часом: $\quad I=q^{\prime}(t)=\lim _{\Delta t \rightarrow 0} \frac{\Delta q}{\Delta t}$, де $q-$ позитивний заряд, що переноситься через переріз провідника.

\begin{tabular}{|c|c|}
\hline Фізична величина & Формули \\
\hline Швидкість & $\begin{aligned} v & =\frac{d}{x}=x^{I} \text { або } v=s^{I}(t) \\
\text { a) } \quad x & =v t, v=(v t)^{I}=v \\
\text { b) } \quad x & =v_{0} t+\frac{a t^{2}}{2}, v=v_{0} t+\left(\frac{a t^{2}}{2}\right)^{I}=v_{0}+d t\end{aligned}$ \\
\hline Прискорення & $a=\frac{d}{v}=v^{r}, v=a t$ або $a(t)=v^{I}(t)$ \\
\hline Потужність & $\begin{array}{l}P=\frac{d A}{d t}=A^{I}, \quad d A=F d x \\
P=\frac{F d x}{d t}=F \frac{d x}{d t}=F v\end{array}$ \\
\hline Сила & $\begin{array}{l}F=m a, \quad a=\frac{d v}{d t} \\
F=m \frac{d v}{d t}=\frac{d(m v)}{d t}\end{array}$ \\
\hline Сила струму & $i=\frac{d q}{d t}=q^{I}$ \\
\hline ЕРС індукції & $\varepsilon_{i}=-\frac{d \Phi}{d t}=-\Phi^{I}$ \\
\hline
\end{tabular}

9) Теплоємність є похідна від кількості теплоти, підведеної до тіла, по температурі даного тіла: $C(t)=Q^{\prime}(t)$.

10) Густина тіла є похідна його маси: $\rho(l)=m^{\prime}(l)$.(див. табл. 1)

Приклад 1. Електричний заряд, який проходить через переріз провідника, змінюється за законом $q(t)=2 t^{2}+3 t$. Знайти закон зміни сили струму у провіднику та силу струму в момент часу $3 c$.

Розв'язання. Знайдемо силу струму за формулою: $\mathrm{I}(t)=q^{I}(t)=6 t^{2}+3$. Підставивши час $t=3 c$ знайдемо миттєве значення сили струму $I(3)=54+3=57 \mathrm{~A}$. 
Журнал «Герспективи та інновації наукњ

(Серія«Гедагогіка», Серія «Гицхологія», Серія«Медицин»»

№4(4) 2021

Приклад 2. Тіло масою 5 кг рухається прямолінійно за законом $S=\frac{t^{4}}{4}-t^{2}+3 t$, де $t$ виражається в секундах, а $S-$ у сантиметрах. Обчислити кінетичну енергію тіла $\left(K=\frac{m V^{2}}{2}\right)$ через 2 секунди.

Розв'язання. Швидкість руху визначимо за формулою $v(t)=S^{\prime}(t)=t^{3}-2 t+3$. Підставимо отримане значення в формулу для обчислення кінетичної енергії та врахуємо вхідні дані $K=\frac{m V^{2}}{2}=\frac{5 \cdot(2-2 \cdot 2+3)}{2}=\frac{35}{2}=17,5 \mathrm{K \Gamma} \cdot \mathrm{cM}^{2} / \mathrm{c}$.

Приклад 3. Кількість електрики, що протікає через провідник 3 моменту часу $t=0$, задається законом $Q=2 t^{3}+4 t+7$ кулонів. Знайти силу струму в кінці п’ятої секунди.

Розв'язання. Силу струму визначимо за формулою $I=Q^{I}(t)=6 t^{2}+4=6 \cdot 5^{2}+4=154(A)$.

Розглянемо вивчення диференціального числення студентами спеціальності 051 «Економіка»

Похідна виступає як швидкість зміни деякого економічного об'єкта (процесу) за часом або відносно іншого об'єкта дослідження. Саме поняття «похідна в економіці» тісно пов'язана з виробничими завданнями, граничними величинами та еластичністю функцій. В економіці дуже часто необхідно знайти значення показників, таких як гранична продуктивність праці, максимальний прибуток, максимальний обсяг випуску продукціі, мінімальні витрати [1, с. 53-54].

\section{Економічний зміст похідної.}

В якості прикладів використання елементів диференціального числення розглянемо поняття середніх та граничних (маргінальних) витрат, доходу, тощо, які широко використовуються в економіці.

Маргінальні витрати визначають як гранично можливі витрати в умовах постійного відтворювання виробництва відповідної продукції.

Витрати, дохід та прибуток виробництва $x$ одиниць продукції позначимо відповідно через $V(x), D(x), P(x)$ які є певними функціями кількості одиниць $x$ виробленої та реалізованої продукції. В разі збільшення підприємством випуску продукції на $\Delta x$ одиниць, то функції одержують приріст:

$$
\begin{aligned}
& \Delta V(x)=V(x+\Delta x)-V(x) ; \\
& \Delta D(x)=D(x+\Delta x)-D(x) ; \\
& \Delta P(x)=P(x+\Delta x)-P(x) .
\end{aligned}
$$

Приріст відповідної функції на одиницю приросту продукції характеризується відношенням приросту функції до $\Delta x$, границя його відношення при $\Delta x \rightarrow 0$ стає маргінальною.

Отже:

маргінальна вартість: $\lim _{\Delta x \rightarrow 0} \frac{\Delta V(x)}{\Delta(x)}=\lim _{\Delta x \rightarrow 0} \frac{V(x+\Delta x)-V(x)}{\Delta(x)}=V^{\prime}(x)$; 
маргінальний дохід: $\lim _{\Delta x \rightarrow 0} \frac{\Delta D(x)}{\Delta(x)}=\lim _{\Delta x \rightarrow 0} \frac{D(x+\Delta x)-D(x)}{\Delta(x)}=D^{\prime}(x)$;

маргінальний прибуток: $\lim _{\Delta x \rightarrow 0} \frac{\Delta P(x)}{\Delta(x)}=\lim _{\Delta x \rightarrow 0} \frac{P(x+\Delta x)-P(x)}{\Delta(x)}=P^{\prime}(x)$.

Таким чином, економічний зміст похідної наступний: похідні $V^{\prime}(x), D^{\prime}(x), P^{\prime}(x)$ дорівнюють маргінальній вартості, доходу та прибутку відповідно. [Барковський, с. 218]

Друга похідна $V^{\prime \prime}(x)$ вказує на швидкість зміни маргінальної вартості відносно зміни кількості випуску продукції.

Границя відношення відносного приросту функції $y=f(x)$ до відносного приросту незалежної змінної, коли $\Delta x \rightarrow 0$, називається еластичністю функції $y=f(x)$ відносно змінної $x$.

Еластичність функції $y=f(x)$ позначимо як

$$
E_{x}(y)=\frac{x}{y} \cdot \frac{d y}{d x} .
$$

Економічна інтерпретація еластичності функції - це наближений відсотковий iї приріст, що відповідає приросту незалежної змінної на $1 \%$. [Берегова, с.346]

Еластичність функції застосовується при аналізі попиту та пропозиції.

Якщо еластичність попиту (за абсолютною величиною) $\left|E_{x}(y)\right|>1$, то попит вважають еластичним, якщо $\left|E_{x}(y)\right|<1$ - нееластичним відносно ціни (або доходу).

Якщо $\left|E_{x}(y)\right|=1$, то йдеться про попит з одиничною еластичністю.

Приклад 1. Обсяг продукції $V$ цеху, який виготовляє новорічні прикраси, протягом однієї зміни (8 годин) виражається формулою $V(t)=\frac{4 t^{3}}{3}+5 \frac{1}{2} t^{2}+40 t+21$, де $t \in[1 ; 8]$. Обчислити продуктивність праці цеху через 3 години від початку роботи.

Розв'язання. $z=V^{\prime}(t)=4 t^{2}+11 t+40=4 \cdot 9+11 \cdot 3+40=110$ (од.)

Приклад 2. Підприємство реалізує свою продукцію за ціною 900 ум.од. за один виріб. Витрати підприємства задаються формулою $S(x)=300 x+2 x^{3}$, де $x$ - обсяг продукції, що випускається. Знайти оптимальний для підприємства обсяг випуску продукції та максимальний прибуток.

Розв'язання. Функція прибутку має вигляд $C(x)=900 x-\left(300 x+2 x^{3}\right)$, де $C(x)$ - прибуток реалізованої продукції. Дослідимо цю функцію на екстремум.

$$
C^{I}(x)=\left(600 x-2 x^{3}\right)^{I}=600-6 x^{2}=0 \quad \text { (при } \quad x_{1}=10 ; x_{2}=-10 \quad \text { не }
$$
задовольняє умові задачі). 
Журнал«Герспективитаінноваціїнауки

(Серія«Гедагогіка», Серія«ГЕихологія», Серія«Медицина»

№4(4) 2021

$C^{\prime \prime}(x)=-12 x<0$, отже при $x=10$ прибуток максимальний. Знайдемо максимум $\quad$ функції $\quad \mathrm{C}_{\max } C(10)=600 \cdot 10-2 \cdot 1000=6000-2000=4000$ (ум.од.)

Приклад 3. Знайти еластичність попиту відносно ціни, якщо функція $y=40-2 x$ ( $x$ вимірюється в гривнях $)$ визначає залежність попиту від ціни.

Розв'язання.

$E_{x}(y)=\frac{x}{40-2 x} \cdot(-2)=\frac{-2 x}{2 x-40}$.

Якщо, наприклад, $x=10$, то $E_{x}=\frac{20}{-20}=-1$. Це означає, при ціні 10 гривень підвищення ціни на $1 \%$ викликає зниження попиту на $1 \%$.

Приклад 4. Витрати виробництва К залежать від обсягу продукції за формулою $K(x)=-x^{3}+1200 x+2000$. При яких значеннях $x$ витрати виробництва почнуть спадати?

Розв'язання.

$K^{\prime}(x)=-3 x^{2}+1200<0$;

$-3\left(x^{2}-400\right)=-3(x-20)(x+20)<0$.

За умовою задачі $x>0$. Отже, витрати начнуть спадати при обсягах $x>20$.

Застосування диференціального числення в задачах хімії та біології основано на визначенні миттєвої швидкості зміни функції.

Так, швидкість хімічної реакції $V(t)=C^{\prime}(t)$, де $\mathrm{C}(t)$ - концентрація речовини, яка вступила в хімічну реакцію в момент часу $t$; [моль/л].

Швидкість зростання популяції $V_{n}=P^{\prime}(t)$, де $P(t)$ - чисельність популяції в момент часу $t$; [особин].

Приклад 5. Кількість бактерій $N$ у деякій біомасі змінюється за законом $N(t)=240+42 t+3 t^{2}$. Скільки бактерій було у біомасі у початковий момент $t=0$ ? Яка швидкість приросту кількості бактерій в момент часу 2 хв.?

Розв'язання. В початковий момент часу $t=0$ у біомасі було 240 бактерій. Оскільки швидкість приросту кількості бактерій $є$ похідною від чисельності популяції, тобто $V(t)=N^{t}(t)$, то $V(t)=\left(240+42 t+3 t^{2}\right)^{t}=6 t+42$. За умови, коли $t=2$ хвилини, то $V(t)=6 \cdot 2+42=54$ бактерії/хвилину.

Приклад 6. Чисельність популяції бактерій у момент часу $t$ (у год) задається формулою $P(t)=10^{5}+10^{3} t-10^{2} t^{2}$. Протягом якого часу популяція зростає? Починаючи з якого моменту чисельність почне зменшуватися?

Розв'язання. Знайдемо похідну розв'яжемо нерівність $P^{\prime}(t)=10^{3} t-2 \cdot 10^{2} t>0$.

$-2 \cdot 10^{2} t>-10^{3}$

$t<\frac{10^{3}}{2 \cdot 10^{2}}$; 
$t<5$.

Чисельність популяції збільшуватиметься протягом 5 годин.

При $t<5, p^{t}(t)<0$, тобто популяція почне зменшуватися.

Висновки. Педагогічний досвід викладання математики в ОВП «КФКТЕ

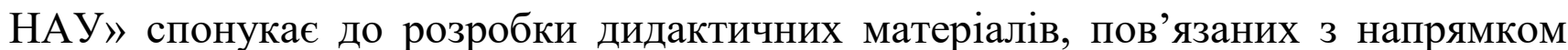
або спеціальністю майбутніх молодших бакалаврів. Розв'язання прикладних задач, задач професійної спрямованості підвищує вмотивованість навчання, зацікавленість студентів у оволодінні та застосуванні математичного апарату в майбутній професійній діяльності, що в свою чергу позитивно впливає на результативність навчання. Застосування прикладних задач, економічних задач $\epsilon$ ефективним засобом формування творчої особистості, сприяє формуванню як математичних, так і професійних компетентностей. Однак перед викладачами математики постають творчі задачі для пошуку та впровадження в практику нових теоретичних понять та розробки практичних завдань 3 різних тем математики відповідно до професійних потреб здобувачів вищої та передвищої освіти.

\section{Лimepamypa:}

1. Барковський В. В., Барковська Н. В. Вища математика для економістів. Київ: ЦУЛ, 2002. $400 \mathrm{c}$.

2. Берегова Г. І., Гладунський В. Н. Математика для економістів: вища математика. Ч. 1. Київ : УБС НБУ, 2014. 374 с.

3. Деркач Ю.В. Підготовка майбутніх фахівців за умов нових технологій навчання. Наук.-метод. зб. Інституту інноваційних технологій і змісту освіти МОН Украӥни. К., 2010. Вип. 61. с. 87-91.

4. Кадемія М.Ю. Формування професійної компетенції майбутнього фахівця. http://www.kpi.kharkov.

5. Кашканова Г.Г. Использование игровых форм обучения общетехническим дисциплинам в процессе формирования профессиональной направленности студентов: автореф. дис. ... канд. пед. наук: 10.00.01. К., 1992. 20с.

6. Антонюк Л.Л., Василькова Н.В., Ільницкий Л.О.. Компетентнісний підхід у вищії освіті: світовий досвід. К.: КНЕУ, 2016. 61с.

7. Морева Н.А. Педагогика среднего профессионального образования. М.: Изд. центр «Академия», 2001. 272 с.

8. Нічуговська Л.І. Формування професійної компетентності в системі математичної підготовки студентів економічного профілю. Дидактика математики: проблеми $i$ дослідження. 2003. Вип. 20. с. 3-12.

9. Стасюк В., Григулич С. Використання похідної функції на прикладах розв’язання економічних задач . Математика в школі. 2008. №5. с. 39-41.

10. Фомкина О.Г. Методична система проведення практичних занять 3 математики зі студентами економічних спеціальностей (на базі кооперативного інституту): автореф. дис. ... канд. пед. наук:13.00.02. К., 2000. 20 с.

11. Чорний В.3., Хохлова Л.Г., Хома-Могильська С.Г. Прикладні аспекти диференціального числення. Тернопіль: «Тайп», 2016. 72 с.

12. Ярмоленко В.О. Вища математика для економістів. Ч.1. Вінниця: Вінніц. торг. економ. ін-т Київ. нац. торг. економ. ун-ту, 2004. 128 с. 


\section{References:}

1. Barkovskyi V.V., Barkovska N.V. (2002). Vyshcha matematyka dlia ekonomistiv. [Higher mathematics for economists] Kyiv: TsUL,. 400 p. [in Ukrainian].

2. Berehova H. I., Hladunskyi V. N. Matematyka dlia ekonomistiv: vyshcha matematyka. [Mathematics for economists: higher mathematics] part. 1. Kyiv : UBS NBU, 2014. 374 p. [in Ukrainian].

3. Derkach Yu.V. (2010). Pidhotovka maibutnikh fakhivtsiv za umov novykh tekhnolohii navchannia. [Training of future specialists under the conditions of new learning technologies.] Nauk.-metod. zb. Instytutu innovatsiinykh tekhnolohii i zmistu osvity MON Ukrainy. K., 61, 87-91 pp. [in Ukrainian].

4. Kademiia M.Iu. Formuvannia profesiinoi kompetentsii maibutnoho fakhivtsia. [Formation of professional competence of the future specialist.] Retrieved from http://www.kpi.kharkov. [in Ukrainian].

5. Kashkanova G.G. (1992). Ispol'zovanie igrovyh form obucheniya obshchetekhnicheskim disciplinam $\mathrm{v}$ processe formirovaniya professional'noj napravlennosti studentov [The use of game forms of teaching general technical disciplines in the process of forming the professional orientation of students]. Extended abstract of candidate's thesis. Kyiv. [in Russian].

6. Antoniuk L.L., Vasylkova N.V., Ilnytskyi L.O. (2016). Kompetentnisnyi pidkhid u vyshchii osviti: svitovyi dosvid. [Competence approach in higher education: world experience.]. K.: KNEU, 61 p. [in Ukrainian].

7. Moreva N.A. (2001). Pedagogika srednego professional'nogo obrazovaniya. [Pedagogy of secondary vocational education]. M.: Izd. centr «Akademiya». 272 p. [in Russian].

8. Nichuhovska L.I. (2003). Formuvannia profesiinoi kompetentnosti v systemi matematychnoi pidhotovky studentiv ekonomichnoho profiliu. [Formation of professional competence in the system of mathematical training of students of economic profile]. Dydaktyka matematyky: problemy $i$ doslidzhennia - Didactics of mathematics: problems and research. Vyp. 20. 3-12 pp. [in Ukrainian].

9. Stasiuk V., Hryhulych S. (2008). Vykorystannia pokhidnoi funktsii na prykladakh rozviazannia ekonomichnykh zadach . [Using the derivative function on examples of solving economic problems]. Matematyka $v$ shkoli-Mathematics at school. 5, 39-41 pp. [in Ukrainian].

10. Fomkyna O.H. (2000). Metodychna systema provedennia praktychnykh zaniat z matematyky zi studentamy ekonomichnykh spetsialnostei (na bazi kooperatyvnoho instytutu) [Methodical system of conducting practical classes in mathematics with students of economic specialties (on the basis of a cooperative institute)]. Extended abstract of candidate's thesis. Kyiv. [in Ukrainian].

11. Chornyi V.Z., Khokhlova L.H., Khoma-Mohylska S.H. (2016). Prykladni aspekty dyferentsialnoho chyslennia. [Applied aspects of differential calculus]. Ternopil: «Taip»,72 p. [in Ukrainian].

12. Yarmolenko V.O. (2004). Vyshcha matematyka dlia ekonomistiv. [Higher mathematics for economists]. part.1. Vinnytsia: Vinnits. torh. - ekonom. in-t Kyiv. nats. torh. ekonom. un-tu,. 128 p. [in Ukrainian]. 